\title{
Circulating level of interleukin- 6 in relation to body mass indices and lipid profile in Egyptian adults with overweight and obesity
}

\author{
Dalia M. E. El-Mikkawy ${ }^{1 *}$, Maha A. EL-Sadek¹, Mohja A. EL-Badawy and Dalia Samaha²
}

\begin{abstract}
Background: Obesity is an important feature of metabolic syndrome, and the link between them has been attributed to the state of chronic inflammatory process.

The purpose of the study is to investigate the relation of circulating level of IL-6 as an inflammatory cytokine to body mass index and lipid profile in adults with overweight and obesity.

Methods: This cross-sectional study included 15 adults with overweight, 45 with obesity (15 grade I, 15 grade II, and 15 grade III), and 25 average weight controls. Circulating IL-6 level and lipid profile were measured.

Results: Highly significant differences were found between study groups in different grades of obesity as regards weight, body mass index, serum triglycerides, and serum LDL-C. Circulating levels of IL6 were significantly higher in subjects with overweight and obesity. There were significantly positive correlations between circulating levels of IL6 and BMI in subjects with grade III obesity and negative correlation with serum HDL-C in subjects with grade II obesity.

Conclusion: High circulating level of IL-6 could reflect the intensity of the chronic and systemic inflammation that develops with high degrees of obesity, which might contribute to the development of atherosclerosis and coronary heart diseases, both directly and by reducing HDL-C levels.
\end{abstract}

Keywords: Interleukin 6, Obesity, Pro-inflammatory cytokines, Body mass index, High-density lipoprotein, Cholesterol

\section{Background}

Obesity has been reported as the most important risk factor for atherosclerosis, ischemic heart disease (IHD), and diabetes [1]. Nowadays, overweight and obesity represent a major public health problem and nutritional disorder that can be attributed to multiple factors including consuming high-energy low-nutrient diet and decreased physical activity [2].

\footnotetext{
*Correspondence: drdaliaezz74@yahoo.com

'Department of Physical Medicine, Rheumatology and Rehabilitation, Ain Shams University Hospitals, Faculty of Medicine, Ain Shams University, 11 Abbass Zaaezooe, 7th District, Nasr City, Cairo 11727, Egypt

Full list of author information is available at the end of the article
}

In obesity, macronutrients' excess in adipose tissues stimulates the release of inflammatory adipokines such as interleukin-6 (IL-6), tumor necrosis factor $\alpha$ (TNF- $\alpha$ ), monocyte chemoattractant protein-1 (MCP-1), and resistin leading to a state of chronic inflammation in obese subjects [3].

Obesity is an important feature of metabolic syndrome, and the link between them has been attributed to the state of chronic inflammatory process $[4,5]$.

IL-6 is a pro-inflammatory cytokine involved in the regulation of inflammatory responses [6]. It is an endocrine cytokine exerting its major effects at sites distinct from its origin depending upon its circulating
Springer Open

(c) The Author(s). 2020 Open Access This article is licensed under a Creative Commons Attribution 4.0 International License, which permits use, sharing, adaptation, distribution and reproduction in any medium or format, as long as you give appropriate credit to the original author(s) and the source, provide a link to the Creative Commons licence, and indicate if changes were made. The images or other third party material in this article are included in the article's Creative Commons licence, unless indicated otherwise in a credit line to the material. If material is not included in the article's Creative Commons licence and your intended use is not permitted by statutory regulation or exceeds the permitted use, you will need to obtain permission directly from the copyright holder. To view a copy of this licence, visit http://creativecommons.org/licenses/by/4.0/. 
concentrations through binding to a membrane-bound $\alpha$ receptor (IL-6R) [7]. IL-6 serum level was found to be increased in obese patients as well as in patients with chronic inflammatory conditions and serum lipid concentrations abnormalities $[8,9]$. The increased IL-6 levels in individuals with obesity may result in increasing the risk of cardiovascular complication, insulin resistance, and type 2 diabetes [10]. Measuring the arteriovenous difference of IL- 6 over the abdominal subcutaneous adipose tissue under basal condition showed that IL-6 is released into the circulation in an adequate concentration to elicit endocrine effects [11]. It was found that one third of total concentrations of circulating IL-6 is released from adipose tissue [12].

Positive associations between body mass index (BMI) and plasma IL-6 levels had been described in postmenopausal women [13]. One of important findings in the study of Baikpour et al. was the significant positive correlation between serum level of IL6 and BMI in healthy subjects with obesity [2]. Furthermore, plasma levels of IL-8 and IL- 6 were found to be correlated with measures of insulin resistance in male subjects with abdominal obesity [14].

The condition of obesity in Egypt lacks similar studies investigating the possible etiological and complicating factors.

The purpose of the study is to investigate the relation of circulating level of IL- 6 as an inflammatory cytokine to body mass index and lipid profile in adults with overweight and obesity.

\section{Methods}

The present cross-sectional study enrolled 60 adult subjects with overweight and obesity, 13 males and 47 females who were recruited. Study was done from March 2018 to January 2019, in duration of 11 months. Their age ranged between 25 and 50 years (mean $36.40 \pm 7.26$ years). Twenty-five healthy adult subjects with normal weight (BMI $<25 \mathrm{~kg} / \mathrm{m}^{2}$ ) matched in age and sex were taken as a control group (6 males and 19 females). Their age ranged between 25 and 50 years (mean $35.60 \pm 7.92$ years).

According to the WHO International Classification of adult underweight, overweight, and obesity according to BMI [15], the present study included 25 controls with normal weight (BMI $<25 \mathrm{~kg} / \mathrm{m}^{2}$, with a range from 19.92 to $\left.24.84 \mathrm{~kg} / \mathrm{m}^{2}\right) ; 25$ controls [2], with a range from 19.92 to $24.84 \mathrm{~kg} / \mathrm{m}^{2} ; 15$ subjects with overweight (BMI $25-29.9 \mathrm{~kg} / \mathrm{m}^{2}$, with a range from 26.12 to $29.97 \mathrm{~kg} / \mathrm{m}^{2}$ ); and subjects with obesity (BMI $\geq 30 \mathrm{~kg} / \mathrm{m}^{2}$ ) ranged from 32.48 to $54.49 \mathrm{~kg} / \mathrm{m}^{2}$. Among the subjects with obesity, 15 were grade I (BMI ranged $\geq 30.00-34.9 \mathrm{~kg} / \mathrm{m}^{2}$ ), 15 grade II obesity (BMI $>35$ to $\leq 39.9 \mathrm{~kg} / \mathrm{m}^{2}$ ), and 15 were grade III obesity (BMI $\geq 40 \mathrm{~kg} / \mathrm{m}^{2}$ ).
For all participants, a detailed medical history was obtained, including comorbid conditions and concomitant medications. A thorough clinical examination was performed. Body mass index was calculated as weight $(\mathrm{kg})$ divided by the square of height $(\mathrm{m}), \mathrm{kg} / \mathrm{m}^{2}$. None of the subjects with overweight and obesity and controls were on a special diet when they were enrolled into the study.

\section{Exclusion criteria}

Excluded from this study were individuals with secondary causes of obesity, diabetic patients ( type I and type II DM), those with severe infectious or inflammatory diseases, those with cancer, pregnant or lactating women, subjects with major systemic diseases (liver, kidney, rheumatic, and cardiovascular diseases), and subjects using medications, including antihypertensive drugs and hypolipidemic agents. Random blood sugar, thyroid profile, liver, and kidney function was done for all subjects for exclusion criteria.

\section{Laboratory analyses}

Blood was collected and immediately put on ice, serum was separated within $2 \mathrm{~h}$ of the collection, and aliquots were stored at $-80^{\circ} \mathrm{C}$ until further analysis.

Serum concentrations of IL- 6 were measured using human ELISA kits (supplied by Bioassay Technology) for both patients and controls, according to the following procedure: $50 \mu \mathrm{l}$ standard/sample/control was added into appropriate wells followed by $50 \mu$ l conjugate (streptavidin-HRP conjugated to anti IL6 antibody); then, the wells were covered and incubated for $60 \mathrm{~min}$ at $37{ }^{\circ} \mathrm{C}$. Washing for 5 times was performed followed by adding $50-\mu \mathrm{l}$ substrate solution $\mathrm{A}$ and $50-\mu \mathrm{l}$ substrate solution $\mathrm{B}$, then incubating for $10 \mathrm{~min}$ at $37^{\circ} \mathrm{C}$ in the dark. Fiftymicroliter stop solution was added, and the absorbance was measured at $450 \mathrm{~nm}$ with reference $630 \mathrm{~nm}$ within $10 \mathrm{~min}$.

Total cholesterol and high-density lipoprotein (HDL) cholesterol and triglyceride (TG) were measured by an enzymatic assay using Beckman Coulter AU680 Auto analyzer. Low-density lipoprotein (LDL) cholesterol was calculated by the Friedewald formula LDL-C: TC - (TG/ 5) - HDL-C.

\section{Statistical analysis}

Statistical analysis of data was performed using the SPSS program version 15 for windows (IBM Corporation, Armonk, NY, USA). Data were presented as "mean (standard deviation, SD)" for parametric variables, "median (interquartile range, IQR)" for non-parametric variables, or "percentage of total" for categorical variables. Student's $t$ test was used to compare quantitative data between both patients and control groups, and the chisquare test was used to compare categorical variables 
between both groups. The Pearson correlation coefficient was used to measure correlations between different quantitative variables. The Mann-Whitney test was used to compare non-parametric variables. The KruskalWallis test was used to compare serum level of IL-6 between overweight and obese subjects in different grades.

One-way ANOVA test was used to compare different parameters between individuals with overweight and obesity presented in different classes. Differences were considered to be significant at $P<0.05$.

\section{Results}

General characteristics and anthropometric measures of control group and study group are shown in Table 1.

There were no significant differences in female to male ratio, age, and height between both groups. Meanwhile, weight and BMI were highly significantly higher in the group of subjects with overweight and obesity (Table 1).

Comparisons of general characteristics, anthropometric measures, and serum lipids between subjects with overweight and obesity in different grades are demonstrated in Table 2.

Highly significant differences were found between subjects with overweight and different grades of obesity as regards weight, BMI, serum TG, and serum cholesterol and only significant differences in serum LDL-C, while non-significant differences were found in serum HDL-C (Table 2).

Comparisons of circulating levels of IL6 in the control group and study group are shown in Table 3 .

Circulating levels of IL6 were significantly higher $(P=$ 0.000 ) in subjects with overweight (BMI $25-29.9 \mathrm{~kg} / \mathrm{m}^{2}$ )

Table 1 General characteristics and anthropometric measures of control group and study group

\begin{tabular}{llllll}
\hline & & Control group & Study group & $P$ value & Sig. \\
& & No. $=25$ & No. $=60$ & & \\
\hline Sex $(n, \%)$ & Female & $19(76.0 \%)$ & $47(78.3 \%)$ & $0.814^{*}$ & NS \\
& Male & $6(24.0 \%)$ & $13(21.7 \%)$ & & \\
Age (years) & Mean \pm SD & $35.60 \pm 7.92$ & $36.40 \pm 7.26$ & $0.653^{\circ}$ & NS \\
& Range & $25-50$ & $25-50$ & & \\
Height $(\mathrm{cm})$ & Mean \pm SD & $160.58 \pm 8.12$ & $161.45 \pm 6.66$ & $0.609^{\circ}$ & NS \\
& Range & $148-180$ & $148-179$ & & \\
Weight $(\mathrm{kg})$ & Mean \pm SD & $59.08 \pm 7.80$ & $94.43 \pm 19.80$ & $0.000^{\circ}$ & HS \\
& Range & $46-75$ & $58-142$ & & \\
BMI $\left(\mathrm{kg} / \mathrm{m}^{2}\right)$ & Mean \pm SD & $22.68 \pm 1.63$ & $36.18 \pm 7.09$ & $0.000^{\circ}$ & HS \\
& Range & $19.92-24.84$ & $26.12-54.49$ & & \\
\hline
\end{tabular}

$P$ value $>0.05$, non-significant; $P$ value $<0.05$, significant; $P$ value $<0.01$ highly significant $B M I$ body mass index

${ }^{*}$ Chi-square test

- Independent $t$ test and subjects with obesity (BMI $>30 \mathrm{~kg} / \mathrm{m}^{2}$ ) compared to those of control subjects (BMI $<25 \mathrm{~kg} / \mathrm{m}^{2}$ ) (Table 3 ).

Comparisons of circulating levels of IL6 between both sexes of subjects with overweight and different grades of obesity are presented in Table 4.

No significant differences of circulating levels of IL6 were found in subjects with overweight and obesity between both sexes and different grades of obesity (Table 4).

Correlations between circulating levels of IL6 and age, anthropometric measures, and serum lipids in subjects with overweight and different grades of obesity are shown in Tables 5 and 6.

There was a statistically significantly positive correlation between circulating levels of IL6 and BMI in subjects with grade III obesity. Meanwhile, a statistically significantly negative correlation between circulating levels of IL6 and serum HDL was found in subjects with grade II obesity. Otherwise, no further significant correlations were found (Table 5).

\section{Discussion}

The present study revealed significantly higher serum levels of IL- 6 in subjects with overweight and obesity as compared to those of healthy controls. Furthermore, a statistically significantly positive correlation was found between circulating levels of IL6 and BMI only in subjects with very severe (grade III) obesity. Also, a statistically significantly negative correlation between circulating levels of IL6 and serum HDL-C was found in subjects with severe (grade II) obesity. Our results match previously published data, as some authors had investigated the relationship between IL- 6 and obesity.

Comparable findings were previously reported in a study of Baikpour et al., and significantly positive correlations were found between serum levels of IL-6, TNF- $\alpha$, IL-8, IL-12, and IL-18 and BMI in 70 healthy subjects with overweight and obesity with BMIs $\geq 25 \mathrm{~kg} / \mathrm{m}^{2}$ [2].

The study of Khaodhiar et al. showed that subjects with obesity had significantly higher serum levels of TNF- $\alpha$, IL-6, and C-reactive protein (CRP) compared with control subjects and that serum levels of IL-6 and CRP were positively correlated with BMI only in subjects with morbid obese, suggesting that IL-6 could be secreted in an endocrine manner in proportion to fat mass expansion with an associated increase in CRP hepatic production [16].

In the study of Rodrigues et al., circulating IL-6 levels were found to be higher in type II diabetic patients with BMI $>30 \mathrm{~kg} / \mathrm{m}^{2}$ compared to other normal weight diabetic patients and controls with obesity. These results suggest that increased BMI values in type II diabetic patients are associated with increased IL-6 levels [17]. 
Table 2 Comparison of general characteristics, anthropometric measures, and serum lipids between subjects with overweight and obesity in different grades

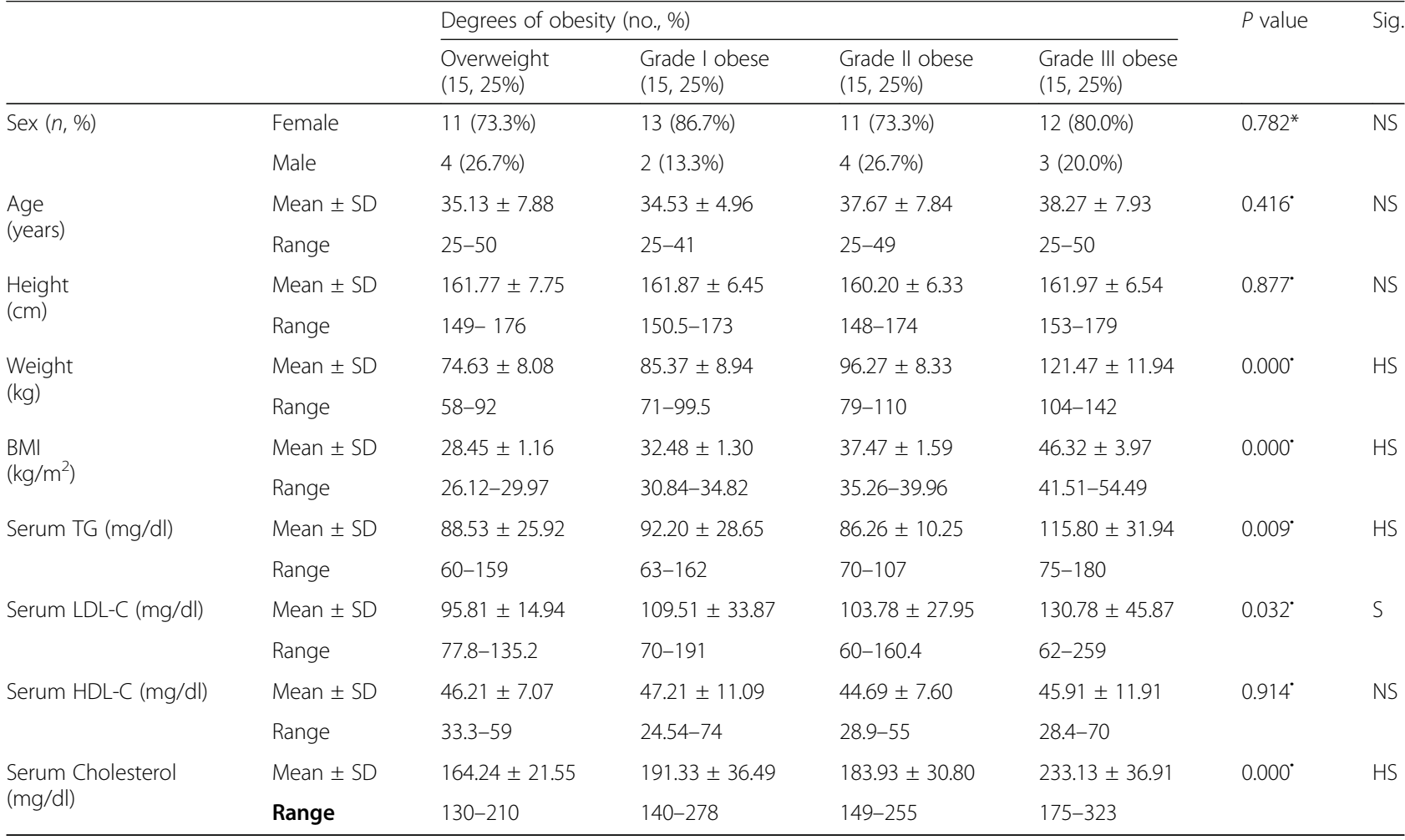

$P$ value $>0.05$, non-significant; $P$ value $<0.05$, significant; $P$ value $<0.01$, highly significant

$B M I$ body mass index, TG triglycerides, $L D L-C$ low-density lipoproteins-cholesterol, HDL-C high-density lipoproteins-cholesterol

${ }^{*}$ Chi-square test

'One-way ANOVA test

In the study of Brunn et al., plasma levels of IL- 8 and IL-6 were found to be increased and correlated with measures of insulin resistance in male subjects with abdominal obesity. Weight loss was associated with reduction of plasma levels of TNF- $\alpha$ and IL- 6 by $25-30 \%$ [14].

There is a close relationship between metabolic pathways and inflammation. Macrophages and adipocytes are directly involved in the production of adipocytokines family members including IL-1, IL6, IL8, IL-12, interferon (IFN), TNF- $\alpha$, transforming growth factor beta (TGF- $\beta$ ), leukemia inhibitory factor (LIF), MCP-1, macrophage inflammatory protein (MIP-1), leptin, and resistin [18].

The death of adipocytes is very common in obese individuals and has been attributed to adipocyte hypoxia secondary to adipose tissue expansion. Adipocyte hypoxia may actively participate in the development of obesity-related inflammation by increasing adipocytokine production and promoting the expression of proinflammatory genes $[19,20]$. That could contribute in possible genetic predisposing factors for obesity and different susceptibility of obesity complications between patients.

The chronic metabolic induced inflammation found in obesity is characterized by a reduced metabolic rate, which contrast the classical non-sterile inflammation that is associated with an increase in metabolism. The state of metabolic induced sterile inflammation is defined as "meta-inflammation." The main central pathophysiologic effect of meta-inflammation is progressive insulin resistance [21].

IL-6 is a multifunctional cytokine secreted by many types of cells, mainly $\mathrm{T}$ cells, macrophages, endothelial

Table 3 Comparison of circulating levels of IL6 in control group and study group

\begin{tabular}{lllll}
\hline & & Non-obese control group & Overweight and obese group & Sig \\
& No. $=25$ & No. $=60$ & value \\
\hline IL6 (Pg/ml) & Median (IQR) & $10(0-25)$ & $120(5-215)$ & $0.000^{*}$ \\
& Range & $0-70$ & $0-640$ & HS \\
\hline
\end{tabular}


Table 4 Comparison of circulating levels of IL6 between both sexes of subjects with overweight and different grades of obesity

\begin{tabular}{|c|c|c|c|c|c|}
\hline & & \multicolumn{2}{|l|}{ IL6 } & \multirow[t]{2}{*}{$P$ value } & \multirow[t]{2}{*}{ Sig } \\
\hline & & Median (IQR) & Range & & \\
\hline \multirow[t]{2}{*}{ Sex } & Female & $120(5-220)$ & $0-640$ & $0.943^{*}$ & NS \\
\hline & Male & $50(20-200)$ & $0-300$ & & \\
\hline Grades of obesity (No, \%) & $\begin{array}{l}\text { Overweight }(15,25.0 \%) \\
\text { Grade I obese }(15,25.0 \%) \\
\text { Grade II obese }(15,25.0 \%) \\
\text { Grade III obese }(15,25.0 \%\end{array}$ & $\begin{array}{l}80(5-280) \\
40(0-140) \\
180(30-220) \\
130(0-200)\end{array}$ & $\begin{array}{l}0-640 \\
0-640 \\
0-270 \\
0-420\end{array}$ & $0.540^{*}$ & NS \\
\hline
\end{tabular}

$P$ value $>0.05$, non-significant; $P$ value $<0.05$, significant; $P$ value $<0.01$, highly significant

${ }^{*}$ Mann-Whitney test

*Kruskal-Wallis test

cells, smooth muscle cells, adipocytes, and hepatocytes [22]. Furthermore, IL- 6 regulates the production of cell adhesion molecules, chemotactic mediators, and acute phase protein and mediates the release of other cytokines that amplify the inflammatory response [23, 24]. IL-6 expression is increased in obese adipose tissue from obese individuals as compared to adipose tissue from lean individuals if normalized for the number of adipocytes [25]. IL-6 receptor expression is increased in the hypothalamus, suggesting a possible role of IL6 in controlling appetite and energy intake [26]. Circulating levels of IL-6 were found to be increased with increasing adiposity and to be associated with the development of obesity-related complications such as cardiovascular

Table 5 Correlation of circulating levels of IL6 to age and anthropometric measures in subjects with overweight and different grades of obesity

\begin{tabular}{|c|c|c|c|}
\hline & \multirow[b]{2}{*}{ Grades of obesity } & \multicolumn{2}{|l|}{ IL6 } \\
\hline & & $r$ & $P$ value \\
\hline \multirow[t]{4}{*}{ Age } & Overweight & 0.193 & 0.492 \\
\hline & I obese & 0.047 & 0.867 \\
\hline & II obese & 0.418 & 0.121 \\
\hline & III obese & 0.080 & 0.777 \\
\hline \multirow[t]{4}{*}{ Height } & Overweight & 0.407 & 0.132 \\
\hline & I obese & 0.237 & 0.396 \\
\hline & II obese & 0.376 & 0.168 \\
\hline & III obese & 0.355 & 0.194 \\
\hline \multirow[t]{4}{*}{ Weight } & Overweight & 0.349 & 0.202 \\
\hline & I obese & 0.318 & 0.248 \\
\hline & Il obese & 0.233 & 0.403 \\
\hline & III obese & 0.174 & 0.535 \\
\hline \multirow[t]{4}{*}{ BMI } & Overweight & 0.038 & 0.893 \\
\hline & I obese & 0.343 & 0.211 \\
\hline & Il obese & 0.197 & 0.482 \\
\hline & III obese & 0.550 & 0.034 \\
\hline
\end{tabular}

$P$ value $>0.05$, non-significant; $P$ value $<0.05$, significant; $P$ value $<0.01$, highly significant

$B M I$ body mass index, $r$ Pearson correlation coefficient diseases and insulin resistance [27-29]. It has been found in both in vitro and in vivo studies that IL-6 is capable of suppressing lipoprotein lipase activity, through which it can cause an increase in circulating lipid levels [30, 31]. Comparable to obesity, a chronic proinflammatory state mostly found in old age is mostly attributed to multiple factors including atherosclerosis, age-related pathological processes, and increased abdominal fat, all of which causing increased circulating levels of IL-6 [32].

Zuliani et al. found that low HDL-C is associated with the presence of high plasma levels of IL-6, in a cohort of older adults independent of multiple potential confounding variables including the main components of the

Table 6 Correlation of circulating levels of IL6 to age serum lipids in subjects with overweight and different grades of obesity

\begin{tabular}{|c|c|c|c|}
\hline & \multirow[b]{2}{*}{ Grades of obesity } & \multicolumn{2}{|l|}{ IL6 } \\
\hline & & $r$ & $P$ value \\
\hline \multirow[t]{4}{*}{ TG } & Overweight & 0.301 & 0.276 \\
\hline & I obese & 0.384 & 0.159 \\
\hline & Il obese & 0.302 & 0.275 \\
\hline & III obese & 0.020 & 0.943 \\
\hline \multirow[t]{4}{*}{ LDL-C } & Overweight & 0.315 & 0.252 \\
\hline & I obese & 0.020 & 0.943 \\
\hline & Il obese & 0.077 & 0.784 \\
\hline & III obese & 0.211 & 0.450 \\
\hline \multirow[t]{4}{*}{$\mathrm{HDL}-\mathrm{C}$} & Overweight & -0.142 & 0.614 \\
\hline & I obese & -0.056 & 0.842 \\
\hline & Il obese & -0.506 & 0.050 \\
\hline & III obese & -0.447 & 0.095 \\
\hline \multirow[t]{4}{*}{ Serum cholesterol } & Overweight & 0.602 & 0.089 \\
\hline & I obese & 0.002 & 0.995 \\
\hline & Il obese & 0.273 & 0.327 \\
\hline & III obese & 0.045 & 0.872 \\
\hline
\end{tabular}


metabolic syndrome, and life style habits such as smoking [32]. A possible mechanism of explanation to the relationship between HDL-C and IL- 6 levels is that IL- 6 as a pro-inflammatory cytokines inhibit the activity of lipoprotein lipase (LPL) [33, 34] and enhance the lipolytic activity of endothelial lipase (EL) [35, 36], both of which have been associated with low HDL-C levels during acute or chronic inflammatory states.

Furthermore, IL-6 effect on HDL-C levels could be indirectly supported by the findings of Popa et al. [37] who found that the treatment of rheumatoid arthritis patients with monoclonal anti-TNF antibodies was accompanied by a decrease in serum levels of IL- 6 and an increase in HDL-C plasma levels, while no change was observed in serum LDL-C and triglycerides levels [37].

Low HDL-C levels leads to a reduction in its atheroprotective role which includes the transport of cholesterol from the sub-endothelial intima to the circulating blood, lowering of oxidative stress, antithrombotic effects, and dampening of inflammation [38], thus leading to a variety of cardiovascular hazards commonly found in subjects with obesity as atherosclerosis and coronary artery diseases.

The results of the present study further emphasize the importance of understanding inflammatory markers' regulation in obesity, the possible development of new therapeutic strategies to prevent the metabolic hazards of obesity, the possible use of IL 6 levels as marker for expectation of obesity complications, and the possible obesity treatment development and complication preventive treatment.

Tocilizumab, a recombinant humanized anti-human IL-6 receptor monoclonal antibody, acts by blocking the binding of IL-6 to the gp80 IL-6 receptor expressed on different cell types, through which it prevents the inflammatory hazards of elevated IL6 [39]. It was found that tocalizumab alleviates symptoms in patients with inflammatory diseases. Administration of tocalizumab in rheumatoid arthritis patients was associated with normalization of acute phase reactants and improvement in disease activity scores [40]. Statins may be helpful in mitigating adverse IL-6 effects on lipid profile [41].

The small sample size, owing to the strict selection criteria for overweight, obese, and control subjects, can be considered as the main limitation of this study. Also, because of the cross-sectional study, we cannot define any cause-effect relationship. Therefore, further longitudinal studies are needed, to better understand the causal pathway that links IL-6 and HDL-C levels in obese adults.

\section{Conclusion}

Circulating levels of IL-6 could reflect the intensity of the chronic and systemic inflammation that develops with high degrees of obesity. High serum levels of IL-6 in subjects with obesity might contribute to the development of atherosclerosis and coronary heart diseases, both directly and by reducing HDL-C levels.

\section{Abbreviations \\ IL: Interleukin; IHD: Ischemic heart disease; TNF-a: Tumor necrosis factor a; MCP-1: Monocyte chemo attractant protein-1; IL-6R: IL-6 receptor; BMI: Body mass index; HDL: High-density lipoprotein; TG: Triglyceride; LDL: Low-density lipoprotein; CRP: C-reactive protein; TGF- $\beta$ : Transforming growth factor beta; LIF: Leukemia inhibitory factor; MCP-1: Macrophage inflammatory protein; LPL: Lipoprotein lipase; EL: Lipolytic activity of endothelial lipase}

\section{Acknowledgements}

No acknowledgement

\section{Authors' contributions}

D M E E M: Contribution to the conception and design of the work; the acquisition, analysis, and interpretation of data; the creation of new software used in the work; and revision. Through suggestion of research idea and aim, clinical assessment of patients and controls, collection of blood samples, and preparation of manuscript and statistical data. Approved the submitted version. Agreed both to be personally accountable for the author's own contributions and to ensure that questions related to the accuracy or integrity of any part of the work, even ones in which the author was not personally involved, are appropriately investigated and resolved and the resolution documented in the literature. M A E S: Contribution to design of the work; interpretation of data; have drafted the work or substantively revised it. Through providence of IL-6 kits, preparation of manuscript and statistical data. Approved the submitted version. Agreed both to be personally accountable for the author's own contributions and to ensure that questions related to the accuracy or integrity of any part of the work, even ones in which the author was not personally involved, are appropriately investigated and resolved and the resolution documented in the literature. M A E $\mathrm{B}$ : Contributions to the conception and design of the work; the creation of new software used in the work; and have drafted the work or substantively revised it. Through clinical assessment of patients and controls, preparation of manuscript and statistical data. Approved the submitted version. Agreed both to be personally accountable for the author's own contributions and to ensure that questions related to the accuracy or integrity of any part of the work, even ones in which the author was not personally involved, are appropriately investigated and resolved and the resolution documented in the literature. D S: Contributions to the conception acquisition and analysis and interpretation of data and have drafted the work or substantively revised it. Through Laboratory assessment of IL-6, preparation of laboratory section in manuscript. Approved the submitted version. Agreed both to be personally accountable for the author's own contributions and to ensure that questions related to the accuracy or integrity of any part of the work, even ones in which the author was not personally involved, are appropriately investigated and resolved and the resolution documented in the literature

\section{Funding}

The research was not funded. Costs were the responsibility of the authors, and instruments used in the study belong to the Faculty of Medicine, a part of Ain Shams University, which is a public governmental organization.

\section{Availability of data and materials}

All data generated or analysed during this study are included in this published article [and its supplementary information files].

\section{Ethics approval and consent to participate}

The study was conducted in accordance with the World Medical Association Declaration of Helsinki for human subjects. The Ethical Committee of Ain Shams University approved the present study.

All subjects signed an informed consent before participation.

Consent for publication

Not applicable. 


\section{Competing interests}

The authors indicate no conflict of interest.

\section{Author details}

'Department of Physical Medicine, Rheumatology and Rehabilitation, Ain Shams University Hospitals, Faculty of Medicine, Ain Shams University, 11 Abbass Zaaezooe, 7th District, Nasr City, Cairo 11727, Egypt. ${ }^{2}$ Department of Clinical Pathology, Ain Shams University Hospitals, Faculty of Medicine, Ain Shams University, Cairo, Egypt.

\section{Received: 27 March 2020 Accepted: 5 May 2020}

\section{Published online: 09 June 2020}

\section{References}

1. Ezzati M, Lopez AD, Rodgers A, Vander Hoorn S, CJL M (2002) Selected major risk factors and global and regional burden of disease. Lancet 360(9343):1347-1360

2. Baikpour M, Baikpour M, Hosseini M, Sarveazad A (2017) Variations in levels of interleukins and adiponectin in normal and obese adults; a case-control study. JMP. 2(2):56-62

3. Ellulu MS, Patimah I, Khaza'ai H, Rahmat A, Abed Y (2017) Obesity and inflammation: the linking mechanism and the complications. Archives of medical scienceAMS 13(4):851

4. Bassuk SS, Rifai N, Ridker PM (2004) High-sensitivity C-reactive protein: clinical importance. Curr Probl Cardiol 29(8):439-443

5. Stępień M, Stępień A, Wlazeł RN, Paradowski M, Banach M, Rysz J (2014) Obesity indices and inflammatory markers in obese non-diabetic normo-and hypertensive patients: a comparative pilot study. Lipids Health Dis 13(1):29

6. Senn JJ, Klover PJ, Nowaki A, Zimmers TA, Koniaris LG, Furlanetto RW et al (2003) Suppressor of cytokine signaling- 3(socs-3), a potential mediator for interleukin-6 dependent insulin resistance in hepatocytes. J Biol Chem 278(16):13740-13746

7. Papanicolau DA (2000) Interleukin-6: the endocrine cytokine. J Clin Endocrinol Metab 85(3):1331-1333

8. Stenlof K, Wernstedt I, Fjallman T, Wallenius V, Wal-lenius K, Jansson JO (2003) Interleukin-6 levels in the central nervous system are negatively correlated with fat mass in overweight/obese subjects. J Clin Endocrinol Metab 88(9):4379-4383

9. Galcheva SV, Lotova VM, Yotov YT, Bernasconi S, Street ME (2011) Circulating proinflammatory peptides related to abdominal adiposity and cardiometabolic risk factors in healthy prepubertal children. Eur J Endocrinol 164(4):553-558

10. Takumansang R, Warouw SM, Lestari H (2013) Interleukin-6 and insulin resistance in obese adolescents. Paediatr Indones 53(5):268-272

11. Mohamed-Ali V, Goodrick S, Rawesh A, Katz DR, Miles JM, Yudkin JS et al (1997) Subcutaneous adipose tissue releases interleukin- 6, but not tumor necrosis factor-alpha, in vivo. J Clin Endocrinol Metab 82(12):4196-4200

12. Fontana L, Eagon JC, Trujillo ME, Scherer PE, Klein S (2007) Visceral fat adipokine secretion is associated with systemic inflammation in obese humans. Diabetes. 56(4):1010-1013

13. Straub RH, Hense HW, Andus J, Scholmerich J, Riegger GAJ, Schunkert H (2000) Hormone replacement therapy and interrelation between serum inter leukin- 6 and body mass index in postmenopause women: a population- based study. J Clin Endocrinol Metab 85(3):1340-1344

14. Bruun JM, Verdich C, Toubro S, Astrup A, Richelsen B (2003) Association between measures of insulin sensitivity and circulating levels of interleukin8 , interleukin-6 and tumor necrosis factor-alpha. Effect of weight loss in obese men. J Clin Endocrinol Metab 148(5):535-542

15. World Health Organization (2004) The international classification of adult underweight, overweight and obesity according to BMI. World Health Organization, Geneve

16. Khaodhiar L, Ling PR, Blackburn GL, Bistrian BR (2004) Serum levels of interleukin- 6 and C-reactive protein correlate with body mass index across the broad range of obesity. JPEN 28(6):410-415

17. Rodrigues KF, Pietrani NT, Bosco AA, Campos FMF, Sandrim VC, Gomes KB (2017) IL-6, TNF-a, and IL-10 levels/polymorphisms and their association with type 2 diabetes mellitus and obesity in Brazilian individuals. AE\&M 61(5):438-446

18. Frühbeck G (2004) The adipose tissue as a source of vasoactive factors. Curr Med Chem Cardiovasc Hematol A 2(3):197-208
19. Hosogai N, Fukuhara A, Oshima K, Miyata Y, Tanaka S, Segawa K et al (2007) Adipose tissue hypoxia in obesity and its impact on adipocytokine dysregulation. Diabetes. 56(4):901-911

20. Ye J, Gao Z, Yin J et al (2007) Hypoxia is a potential risk factor for chronic inflammation and adiponectin reduction in adipose tissue of ob/ob and dietary obese mice. Am J Physiol Endocrinol Metab 293(4):E1118-E1128

21. Gregor MF, Hotamisligil GS (2011) Inflammatory mechanisms in obesity. Annu Rev Immunol 29:415-445

22. Barton BE (1996) The biological effects of interleukin 6. Med Res Rev 16(1): 87-109

23. Kamimura D, Ishihara K, Hirano T (2003) IL-6 signal transduction and its physiological roles: the signal orchestration model. Rev Physiol Biochem Pharmacol 149:1-38

24. Fisman EZ, Tenenbaum A (2010) The ubiquitous interleukin-6: a time for reappraisal. Cardiovasc Diabetol 9:62

25. Fried SK, Bunkin DA, Greenberg AS (1998) Omental and subcutaneous adipose tissues of obese subjects release interleukin-6: depot difference and regulation by glucocorticoid. J Clin Endocrinol Metab 83(3):847-850

26. Stenlof $K$, Wernstedt I, Fjallman T, Wallenius V, Wallenius $K$, Jansson JO (2003) Interleukin-6 levels in the central nervous system are negatively correlated with fat mass in overweight/obese subjects. J Clin Endocrinol Metab 88(9):4379-4383

27. Kern PA, Ranganathan S, Li C, Wood L, Ranganathan G (2001) Adipose tissue tumor necrosis factor and interleukin-6 expression in human obesity and insulin resistance. Am J Physiol Endocrinol Metab 280(5):E745-E751

28. Lowe G, Woodward M, Hillis G, Rumley A, Li Q. Harrap S et al (2014) Circulating inflammatorymarkers and the risk of vascular complications and mortality inpeople with type 2 diabetes and cardiovascular disease or riskfactors: the Advance Study. Diabetes. 63(3):1115-1123

29. Ridker PM, Rifai N, Stampfer MJ, Hennekens CH (2000) Plasma concentration of interleukin- 6 and the risk of future myocardial infarction among apparently healthy men. Circulation. 101(15):1767-1772

30. Greenberg AS, Nordan RP, Mclntosh J, Calvo JC, Scow RO, Jablons D (1992) Interleukin 6 reduces lipoprotein lipase activity in adipose tissue of mice in vivo and in 3 T3-L1 adipocytes: a possible role for interleukin 6 in cancer cachexia. Cancer Res 52(15):4113-4116

31. Van Hall G, Steensberg A, Sacchetti M, Fischer C, Keller C, Schjerling P et al (2003) Interleukin-6 stimulates lipolysis and fat oxidation in humans. J Clin Endocrinol Metab 88(7):3005-3010

32. Zuliani G, Volpato S, Blè A, Bandinelli S, Corsi AM, Lauretani F et al (2007) High interleukin-6 plasma levels are associated with low HDL-C levels in community-dwelling older adults: the In Chianti study. Atherosclerosis. 192(2):384-390

33. Grunfield C, Feingold KR (1996) Regulation of lipid metabolism by cytokines during host defence. Nutrition. 12(1):S24-S26

34. Hardardottir I, Grunfeld C, Feingold KR (1994) Effects of endotoxins and cytokines on lipid metabolism. Curr Opin Lipidol 5(3):207-215

35. Jin W, Millar JS, Broedl U, Glick JM, Rader DJ (2003) Inhibition of endothelial lipase causes increased HDL cholesterol levels in vivo. J Clin Invest 111(3):357-362

36. Jin W, Sun SS, Marchadier D, Octtaviani E, Glick JM, Rader DJ (2003) Endothelial cells secrete triglycerides lipase and phospolipase activities in response to cytokines as a result of endothelial lipase. Circ Res 92(6):644-650

37. Popa C, Netea MG, Radstake T, Van der Meer JW, Stalenhoef AF, Van Riel PL Barerra P (2005) Influence of anti-tumour necrosis factor therapy on cardiovascular risk factors in patients with active rheumatoid arthritis. Ann Rheum Dis 64(2):303-305

38. Oda MN (2015) High-density lipoprotein cholesterol: origins and the path ahead. Curr Opin Endocrinol Diabetes Obes 22(2):133-141

39. Hashizume M, Tan SL, Takano J, Ohsawa K, Hasada I, Hanasaki A et al (2015) Tocilizumab, a humanized anti-IL-6R antibody, as an emerging therapeutic option for rheumatoid arthritis: molecular and cellular mechanistic insights. Int Rev Immunol 34(3):265-279

40. Soubrier M, Pei J, Durand F, Gullestad L, John A (2017) Concomitant use of statins in tocilizumab-treated patients with rheumatoid arthritis: a post hoc analysis. Rheumatol Ther 4(1):133-149

41. Kaly L, Rosner I (2012) Tocilizumab - a novel therapy for nonorgan-specific autoimmune diseases. Best Pract Res Clin Rheumatol 26(1):157-165

\section{Publisher's Note}

Springer Nature remains neutral with regard to jurisdictional claims in published maps and institutional affiliations. 